\title{
The Ket Language
}

\author{
Alexandra A. Sitnikova* \\ Siberian Federal University \\ 79 Svobodny, Krasnoyarsk, 660041, Russia
}

Received 06.03.2018, received in revised form 11.04.2018, accepted 14.04.2018

This article is of the applied research nature, which was carried out within the framework of the cultural project on preserving the culture of the Krasnoyarsk Krai indigenous peoples by creating the children's literature in these peoples' languages. The article presents the key characteristics of the Ket language and culture: the place of the Kets' residence, the issue of ethnogenesis, the Kets' art, shamanism, totem beliefs and other aspects. The main part of the article analyzes the available linguistic materials about the Ket language and describes the corpus of texts in the Ket language that are currently available to the public. Particular emphasis is given to the value of digitizing the linguistic data on the Ket language in the context of modern culture virtualization and need for interdisciplinary researches of the Ket language (linguistics and cultural studies). The article hypothesizes that the linguistic data on the Ket language, which were accumulated during the $20^{\text {th }}$ - the beginning of the $21^{\text {st }}$ centuries, can be used as the basis for further culturological research of the key concepts of the Ket culture (the "bear", for example). They will allow to reconstruct the picture of the world in the culture of the indigenous peoples of the Siberian North. They will also result in a social design of the methods for the Kets' authentic culture effective preservation and development by publishing the children's literature in the Ket language for teaching the native Kets their language from pre-school age.

Keywords: the Ket language, the Ket culture, the Yenisei languages, the culture of the Krasnoyarsk Krai indigenous peoples, the text corpora in the Ket language.

The reported study was funded by Krasnoyarsk Regional Fund of Science according to the research project: «Development of scientific and methodological support for the preservation of a unique cultural heritage for the Ket and Enets ethno-cultural groups of indigenous small peoples of the North, Siberia and the Far East living on the territory of the Krasnoyarsk Territory.

DOI: 10.17516/1997-1370-0257.

Research area: culturology.

\section{Introduction}

The most topical contemporary cultural problems for Krasnoyarsk Krai are the need to understand the peculiar features of culture of the indigenous peoples living in the territory of the krai, as well as the analysis of the opportunities and development of effective technologies for preserving the indigenous peoples' traditional culture and languages on the verge of extinction. The Ket culture and the Ket language are those of the eight cultures of the indigenous peoples living in Krasnoyarsk Krai together with the Nganasans, Dolgans, Evenks, Selkups, Nenets, Enets and Chulyms. They are in need of the special

(C) Siberian Federal University. All rights reserved

* Corresponding author E-mail address: sem_dobrianka@mail.ru 
measures for preservation and, possibly, further development. Despite the fact that the number of the Kets, living mainly in Turukhansk district of Krasnoyarsk Krai, is not so great (according to the 2010 all-Russian census, they were only 957), the Ket language can be considered quite properly studied. The language was subject to the analysis by the scholars from the end of the $18^{\text {th }}$ century. So, it is thoroughly analyzed from a linguistic point of view. Due to the fact that the Ket language is the only Yenisei language that survived, its sounding and existence in the natives' speech are documented with the help of audio and video equipment; the documentary materials, collected during the expeditions by different groups of scholars, are digitized and made available to the public. Moreover, the development of the corpus of the Ket texts has been actively carried out by several groups of scholars, the materials of the corpus of the Ket texts being partly presented on the Internet. This article aims at providing an analytical overview of currently available resources for the study of the Ket language and at identifying the prospective areas for culturological studies of the Ket language.

\section{Literature review}

The scientific literature on the Ket language can be divided into several groups.

The first group presents the studies of the Ket language in the Russian Empire (late $18^{\text {th }}-$ early $20^{\text {th }}$ centuries). At this time the Ket language was first described by the scholars. P.S. Pallas, a German scientist, in his Travels Through the Provinces of the Russian State and M.A. Castrén, a Finnish linguist, in his Journey to Siberia (1845-1849) (Reiseberichte und Briefe aus den Jahren 1845-1849) made their first attempts to reflect over the Ket culture and the uniqueness and logic of the Ket language.

The second group focuses on the studies of the Ket language in the Soviet Union.
In the 1920s, the Soviet scholars began the development of the written Ket language, and primarily the compilation of the alphabet (the Ket language in Latin was compiled in 1934 by Nestor Konstantinovich Karger, a Leningrad ethnographer, for the middle-Ket dialect, which is considered the least common dialect of the language). But in 1935 the scholar was subject to repression and, consequently, the attempts to create the Ket written language were suspended for some time. The studies of the Ket culture and the Ket language continued in the late 1960s. E.A. Alekseenko's book Kety. Istorikoetnograficheskie ocherki (The Kets. Historical and Ethnographic Essays) presents the materials describing the Kets' life, geography of settlement, beliefs, language, as well as changes in the places of the Kets' traditional residence in the Soviet era, the materials being valuable for culturological studies. In the late 1960 s, the research centre for the study of the Ket culture and language moved to Tomsk, and namely to Tomsk State Pedagogical University, a place where Andrei Petrovich Dul'zon worked. Dul'zon was a linguist, ethnographer and archaeologist and received the state prize for Ketskii Iazyk (The Ket Language (1968)), one of the fundamental works in this field. Nowadays, the university organizes the famous "Dulzon readings" highlighting the current researches and issues of Siberian languages. Genrikh Kasparovich Verner was Dul'zon's student. He developed the Ket written language, including the Ket alphabet in Cyrillic letters, the $\mathrm{ABC}$ book, and school textbooks that were initially used for teaching the language in some places of the Kets' residence (e.g., Kellog). It should be noted that Verner's textbooks, written for the schoolchildren in a simple and clear language and offering not only a formal scientific description of various linguistic characteristics of the language but also the explanations of 
some meaningful logic of the language, serve the sources for identifying the conceptual meanings of the Ket culture. In Soviet times, such scholars as V.N. Toporov, B.A. Uspenskii and others studied the Ket language. They based their researches on the materials they got during their field expeditions.

The third group presents the latest research and scientific development in the field of the Ket language in the late $20^{\text {th }}$ - early $21^{\text {st }}$ centuries. At the present stage of a scientific interest to the Ket language there function several research centres and there distinguished several scientific fields of research. Tomsk (Tomsk State Pedagogical University) should be definitely mentioned as a scientific centre of the Ket language analysis. It was Dul'zon who founded the most serious scientific linguistic school for the study of Siberian, Yenisei languages (and the Ket language, in particular). E.A. Kriukova is one of the key representatives of this scientific school. The second important centre for the research of the Ket, Selkup and Evenki languages is the Research Computing Centre of Moscow State University named after M.V. Lomonosov. Since 2001 O.A. Kazakevich has been supervising a digital project "Siberian Lang. Minority Languages of Siberia: Our Cultural Heritage" providing the access to the text, audio and video files with the recordings of the native Kets' speech. This resource contains a whole range of materials on the basis of which the text corpora in the Ket language can be developed, it being one of the most essential tasks of modern linguistics. In some other Siberian cities the linguistic research of the Ket language is also carried out. For example, in Novosibirsk (Novosibirsk State Technical University) a considerable number of articles on the Ket linguistics were written by S.S. Butorin. Yet, we can hardly say that autonomous scientific schools were founded in these cities. At the beginning of the $21^{\text {st }}$ century, in Krasnoyarsk the studies of ethnography and culture of the Siberian peoples and, more specifically, of the indigenous peoples living in the territory of Krasnoyarsk Krai are there are actively carried out. V.P. Krivonogov and N.P. Koptseva, the head of the scientific staff of the Department of Cultural Studies at Siberian Federal University, are involved in collecting and culturological interpretation of the materials as well as development of modern effective methods of the Siberian indigenous peoples' culture preservation. Yet, the Ket people's culture has not been in the centre of attention for the scholars of the department up until present.

Apart from the Russian researchers, the Ket language is also studied by Edward Vajda, an American linguist from the University of Alaska at Fairbanks. He has been carrying out a comparative research of the Ket language and the Na-Dene peoples' language in North America, and has revealed the similarities of these languages.

\section{Research}

\section{Key characteristics of the Ket language and culture}

The Kets are an indigenous people of Siberia. They live mainly in the territory of Turukhansk region of Krasnoyarsk Krai. In Krasnoyarsk Krai there are six geographically compact groups of the Kets' settlements: Elogui (Kellog village on the Elogui river), Surgutikha (Surgutikha village on the river with the same name), Pakulikh (Baklanikha village on the Yenisei), and Kurei (Serkovo village on the Kureika river and Maduika village on the lake Maduiskoe) groups are in Turukhansk district; Sym group (Sym village on the river Sym) in Yenisei district; and Podkamennotungus group (Sulomai village on the Podkamennaia Tunguska river). According to the 2010 all-Russian census, 957 Kets live in Krasnoyarsk Krai. The data about 
the Kets' number vary (for example, according to the Ethnologue. Languages of the World resource their number reaches 1220 people; Professor V.P. Krivonogov's expedition in 2003 states that the Kets are only 885 people. When analyzing the number of the Kets, the researchers always emphasize the fact that not all the Kets speak their native language; thus, the number of the Kets who are native speakers of this language is much fewer (most scholars believe that these Kets are no more than 150 people).

The name of the nation comes from the Ket word ket which means "a man". The Kets belong to the Yenisei peoples who were quite numerous in the $18^{\text {th }}-19^{\text {th }}$ centuries. The Arins, Assans, Kotts, Yugs and Pumpokolls were among them. By the $21^{\text {st }}$ century only the Kets survived. According to G.K. Vagner, having disappeared, these peoples did not leave precise information about their origin, and thus the issue of the Yenisei peoples' and the Kets' ethnogenesis is still open. Various hypotheses are put forward. They suggest the Kets connection with the peoples of Tibet, the Caucasus, southern Siberia and the North American Indians (due to their linguistic kinship). According to the most common theory, the Kets' ancestors lived in southern Siberia. In the $9^{\text {th }}-13^{\text {th }}$ centuries the groups of the Kets began moving to the north after they had met with other nationalities and faced the climatic factors. The Kets' distinctive culture developed in the process of their contacts with the Khanty people and the Selkups, as well as of the Enets people's assimilation.

The Kets' traditional occupations are hunting for ungulate animals, mass fishing, and furs. Initially they led a nomadic life. What distinguishes the Kets from many other peoples of the Siberian north is the fact that reindeer herding is not a determinant type of this people's economic activity, although there is a group of the deer Kets.
The peculiar features of the Ket culture are ethnic costumes, musical instruments (a jew's harp, a musical bow, a stringed lute). The developed fine arts were embroidery with a deer's hair, fur appliqué work.

The Kets' beliefs are connected with the cult of worshiping the forces of nature and shamanism. Yet, unlike many other cultures of the indigenous peoples of Siberia, the Kets have their Supreme God Es', who lives in heaven in the upper circle of being. Identification of the Supreme God made it possible for some researchers to draw parallels between the Kets' beliefs and Christianity. In the Ket religion the old woman Hasiadiam confronts the kind and wise Es'. She is the head of the earthly world. She was exiled there by Es' and, thus, confronted the good forces and was the source of threats and misfortunes for the people. Some totem animals were significant for the Kets, the main animal being the bear. The loon, the swan, and the eagle were culturally important birds. Their family shrine was the fire.

The Ket language belongs to the group of the Yenisei languages. It is considered to be under the threat of extinction, being, perhaps, the second one after the Enets language regarding the degree of the threat of extinction among the the Krasnoyarsk Krai indigenous peoples' languages. There are three types of the Ket language dialects: 1) the southern Ket dialect (Sumarokovo, Sulomai, Bor, Bakhta, Verkhneimbatsk, Kellog) is divided into the Elogui and Podkamennotungus speeches; 2) the central dialect (Surgutikha, Vereshchagino, Baklanikha, Farkovo, Turukhansk); 3) the northern dialect (Maduika, Sovrechka, Igarka, Goroshikha). The differences between the dialects are minor. Their speakers are capable to understand each other. The most common southern dialect of the Ket language was used as a literary model in the written language creation. 


\section{Linguistic research of the Ket language}

Since the Ket language is the only preserved Yenisei language (this implies that nowadays the native speakers of the Ket language can be found in the places of the Kets' traditional residence), the linguistic researches are actively carried out regarding all the levels of language - lexical, phonetic, morphological, grammatical and syntactic. The Russian scholars' key publications, presented in the RSCI database, serve the evidence that the Ket language is given a proper linguistic description: the phonetic features of the language are defined, the main parts of speech in the Ket language are distinguished, the word formation system is analyzed, the grammatical features and principles of building the sentences in the Ket language are specified (the latter are very often compared with the Russian language). The works on the Ket language lexicology are probably of the greatest interest for the culturologists. They state the principle of geographical, temporal, and qualitative nominations in the Ket language, present some interesting facts about it (for example, the information about the colour characteristics: in Ket the non-derivative words are used to nominate white, black and red colours, the word for the nomination of the yellow colour is derived from the word with the meaning of "bile", nominations for blue and green are borrowed from Russian). There is other useful information for understanding the Ket culture in these works. The research on the origin of the proper names and the names of objects in the Ket language are very significant. For example, a special focus of attention is given to the description of the Ket authentic proper names. First, each person had a "surname which stated a qualitative characteristic feature of his/her clan", later these surnames were replaced by the Russian ones. So, some Ket families could have the surname of "a man of water", etc. This kind of linguistic researches is often subject to the logic of one science, to the task of making a list of the Ket language units and their description. They are rarely interdisciplinary in nature and leave the "clues" for the language data to be used by other sciences. Yet, such researches are necessary in the light of the future ambitious goal of linguistic science, the goal being the compilation of digital corpora of texts in national languages, the Ket language in particular. It is so because the text corpora compilation requires a full description of the text units and words (indication of the part of speech, the specific features of the word functioning in the text, etc.).

Many linguistic studies are focused on the issues of the Ket population's bilingualism (Ket - Russian) and trilingualism (Ket - Evenki Russian). They describe the problems and typical situations of switching from one language to another in oral speech, in communication with scientists, etc. In their conclusions these researches often state the disappointing statistic data indicating the absorption of Ket by the Russian language and predict the imminent death of the language under the pressure of the Russian culture. Yet, unlike the Soviet period during which the younger generation tried to emphasize their belonging to the Russian-speaking population, the beginning of the $21^{\text {st }}$ century shows the opposite. The Ket younger generation is willing to know their native language, but the opportunities to study it are extremely limited in modern reality.

Another turn in modern linguistic research is digital linguistics, which is developed in the Research Computing Centre at Moscow State University named after M.V. Lomonosov. Given the RGNF and RFBR support, O.A. Kazakevich has been running the project "Siberian Lang. Minority Languages of Siberia: Our Cultural Heritage". Translation of documents and materials in a disappearing language into a digital format is one of modern forms of language data preservation. 
Working on such projects, the linguists interact with IT professionals and master the programming languages (Python is often used as the most understandable programming language). To date, this electronic resource provides the users with the following documents and the opportunities to get to know the Ket language: 1) the dictionary; 2) the photos; 3) the texts - the episode from the fisherman's life Mordushka (The Cage Trap) (G.M. Bal'din, a narrator, the village of Kellog, 2005); a hunting story Sobolinaia Doroga (The Sable Road) and the mythological tale Ded-starik (Grandfather, the Old Man), recorded by G.M. Korsakov, a scholar, in 1937; the description of shamanistic rituals in the story by an inhabitant of Sulomai village in the 2004 expedition materials; the mythological tale Dotam, recorded by G.M. Korsakov, a scholar, in 1937; Alla Pugacheva's pop songs translated into the Ket language and recorded in 2005 in Kellog village; the tale about the animals Zaiats $i$ Glukhar' (The Hare and the Cock of the Wood), recorded in Kellog village in 2009; and other stories from the Kets' life, recorded during the expeditions of different years (about 5 stories); 4) video recordings of the stories; 5) the movie Kety Munduiskogo Ozera (The Kets of the Lake Mundui) (30 min); 6) language games for training the knowledge of the Ket language; 7) the RFBR syntactic project (the Ket corpus of written texts, including G.K. Verner's Pesn' o Moem Brate: na ketskom iazyke (The Song About my Brother: in the Ket Language), which tells about the Kets' life in the Soviet era. All texts are presented on the site with the translation into Russian. They also contain some linguistic characteristics (phonetic transcription) of some words and phrases in Ket.

\section{Prospects of culturological studies of the Ket language}

A perspective methodological approach for further researches of the Ket language is the concept-analysis of the Ket language. Thes method allows to trace the connection of the Ket language features with the Kets' worldview. This will ultimately contribute to a comprehensive description of the picture of the world of the indigenous population of Siberia, the harmonious existence of the humans and nature in climatic and economic conditions of the region. For example, the concept bear is regarded to be important for the research in the context of the Ket culture since culturological information indicates the particular significance of this animal in the Ket culture and language. In Ket these are euphemisms that are used to nominate the bear (for example, an old man). The phrase with the meaning "the bear succumbed, surrendered to a man" is used instead of the phrase "to kill a bear". According to the Kets' religious beliefs, the bear has a soul, is referred to as a "forest man", the dead ancestors' souls transmigrate into the bears, etc. In their ritual culture the Kets refer to the bearish holidays with the theatrical rituals. Thus, the bear occupies an important place in the Kets' hunting culture. The research, considering the Kets' conceptual ideas about the bear as compared to a central role of the deer in many other cultures of the Siberian peoples, will result in a clearer understanding of the conceptual basis of these indigenous peoples' life. The second important method of the Ket culture analysis, which bases on the Ket language knowledge as the basis of ethnic culture, is the social design involving the development of a number of effective measures to preserve the disappearing language in the modern world. Publication of the children's literature in the Ket language in order to give the younger generation of the Kets an opportunity to learn their native language at preschool age is one of such tools.

\section{Conclusions}

The article presents the analysis of contemporary studies of the Ket language, including two areas of knowledge. These areas are 
fundamental linguistic works on Ket phonetics, grammar, lexicology, morphology, and syntax and digital linguistics, involving the introduction of analogous documents about the Ket language to the space of virtual communication in order to preserve the data about the language and compilation of the text corpora in Ket, the corpora being highly essential at the beginning of the $21^{\text {st }}$ century.

The article lists the main resources, which are available at the beginning of the $21^{\text {st }}$ century, for the research of the Ket language and acquaintance with the authentic texts in Ket (with their translations into Russian).

The article defines two vectors for the topical culturological studies of the Ket language. These are the conceptual studies of the Ket language (for example, the study of the concept bear) and the social design of the effective measures to preserve the Ket language, one of the possible measures being the creation of the children's literature in Ket for the younger generation of the Kets.

\section{References}

Alekseenko, E.A. (1967). Kety (istoriko-etnograficheskie ocherki) [The Kets (Historical and Ethnographic Essays)]. Leningrad, Nauka.

Butorin, S.S. (2015). Obshchaia kharakteristika neglagol'nykh lokativnykh predikatov v ketckom iazyke [General Characteristics of Nonverbal Locative Predicates in the Ket Language], In Siberian Philological Journal, 2, 142-152.

Castrén, M.A. Puteshestvie v Sibir' (1845-1849) [The Journey to Siberia (1845-1849). Available at: http://irkipedia.ru/content/puteshestvie_v_sibir_1845_1849_kastren_ma_1860

Dul'zon, A.P. (1968). Ketskii iazyk [The Ket Language]. Tomsk, Tomsk University Publishing House.

Ivanov, V.V., Toporov, V.N., Uspenskii, B.A. (1968). Ketskii sbornik. Lingvistika [The Ket Collection of Papers. Linguistics]. Moscow, Glavnaia Redaktsiia Vostochnoi Literatury.

Kabanova, T.A. (2002). Mozhno li formalizovat' ketskii iazyk? [Is It Possible to Formalize the Ket Language?], In Tomsk State Pedagogical University Bulletin. Series: Humanities (Philology), 1 (29), 58-62. Available at: http://vestnik.tspu.edu.ru/files/vestnik/PDF/articles/ kabanova_t._a._58_62_1_29_2002.pdf

Kamaeva, E.M. Korpus ketskikh i evenkiiskikh tekstov [The Corpus of the Ket and Evenki Texts]. Available at: http://www.dialog-21.ru/media/3990/kamaeva.pdf

Kazakevich, O.A. (2010). Evenkiisko-ketskaia ekspeditsiia 2009 g.: dokumentatsiia ischezaiushchikh iazykov i dialektov [The Evenki-Ket Expedition of 2009: Documentation of the Endangered Languages and Dialects], In Bulletin of the Russian Foundation for Humanities, 3 (60), 206-2012. Available at: https://elibrary.ru/download/elibrary_23947356_69472787.pdf

Kazakevich, O.A. (2016). Ketskii Iazyk [The Ket Language]. Moscow, Azbukovnik.

Ket. Ethnologue. Languages of the World. Available at: https://www.ethnologue.com/language/ket

Ketskii iazyk: slovar' (audioslovar' s proiznosheniem nositelei iazyka) [The Ket Language: Dictionary (Audio Dictionary with the Native Speakers' Pronunciation). Available at: http://minlang. srcc.msu.ru/ru/slovar?field_lang_filter_tid $=44 \&$ field_rfrns_place_tid $=$ All\&field_rfrns_dictor_ nid $=$ All\&page $=2$

Ketskii iazyk: spravochnaia informatsiia [The Ket Language: Reference Information]. Available at: http://lingvotech.com/ketsky 
Kety munduiskogo ozera: dokumental'nyi fil'm [The Kets of the Lake Mundui: a Documentary Film]. Available at: http://minlang.srcc.msu.ru/ru/video/kety-munduyskogo-ozera

Koptseva, N.P., Khizhniakova, A.N., Reznikova, K.V. (2017). K voprosu o kontseptakh iazykov korennykh narodov Krasnoiarskogo kraia [On the Concepts of the Krasnoyarsk Krai Indigenous Peoples' Languages], In Severnye arkhivy i ekspeditsii [Northern Archives and Expeditions], 1 (1), 6-22.

Kotorova, E.G., Nefedov, A.V. (2006). Problema predstavleniia etnokul'turnykh realii v slovare minoritarnogo iazyka (na primere ketskoi leksiki) [The Problem of Presenting Ethnocultural Realia in a Minority Language Dictionary (the Case of KET)], In Tomsk Journal of Linguistics and Anthropology, 3 (13), 24-32. Available at: https://ing.tspu.edu.ru/files/ling/PDF/articles/ kotorova_e._g._24_32_3_13_2016.pdf

Kriukova, E.A. (2013). Ketskii Iazyk: Ot opisatel'noi lingvistiki k mezhdistsiplinarnym issledovaniiam [The Ket Language: From Descriptive Linguistics to Interdisciplinary Research], In Tomsk Journal of Linguistics and Anthropology, 1 (1), 38-44. Available at: https://elibrary.ru/download/ elibrary_19123416_43668649.pdf

Krivonogov, V.P. (2003). Kety: Desiat' let spustia [The Kets: Ten Years Later (1991-2001)]. Krasnoyarsk, KSPU.

Luk'ianenko, A.G., Felde, O.V. (2001). Iazykovaia situatsiia ketskogo poseleniia Sulomai [The Language Situation of the Ket Settlement of Sulomai], In Siberia Lingua, 1, 69-73. Available at: http:// ifiyak.sfu-kras.ru/sites/default/files/content/doc/Lingua_Sibir__3_.pdf

OLAC (Open Language Archive Community) Resources In and About the Ket Language. Available at: http://www.language-archives.org/language/ket

Pallas, P.S. Puteshestvie po raznym provintsiiam Rossiiskogo gosudarstva. Chast' tret'ia. Pervaia polovina. Puteshestvie po Sibiri k Vostoku lezhashchei dazhe do samoi Daurii v 1792 godu [Travels Through the Provinces of the Russian Empire. Part Three. The First Half. Travels Across Siberia, stretching up to Dauria, to the East in 1792]. Available at: http:/www.runivers.ru/upload/iblock/caa/ Pallas-Puteshestvie\%20po\%20raznim\%20mestam_3-1\%20tom.pdf

Polenova, G.T. (2015). O chem mozhet rasskazat' ketskaia skazka? [What Can the Ket Tale Tell About?]. In Proceedings of Voronezh State University. Series: Linguistics and Intercultural Communication, 3, 52-55. Available at: https://elibrary.ru/download/elibrary_25942826_45283639.pdf

Poliakov, V.A. (1984). Sposoby leksicheskoi nominatsii v sovremennykh eniseiskikh iazykakh (na material iugskogo i ketskogo iazykov) [The Means of Lexical Nomination in Contemporary Enisei Languages (the case of the Yug and Ket Languages). Leningrad.

Seleznev, E.S. Na zemle drevnikh ketov [On the Land of Ancient Kets]. Taishet 24. Informatsionnoe agenstvo [Taishet 24. News agency]. Available at: http://www.t24.su/?page_id=4688

Sokolova, Z.P. (2002). Kul't medvedia i medvezhii prazdnik v mirovozzrenii i kul'ture narodov Sibiri [The Bear Cult and the Bear Festivity in the Worldview and Culture of Siberian Peoples], In Etnos i Kul'tura [Ethnos and Culture], 1, 41-62. Available at: http://journal.iea.ras.ru/archive/2000s/2002/ Sokolova_2002_1.pdf

Teksty na ketskom iazyke. Siberian Lang. Malye iazyki Sibiri: nashe kul'turnoe nasledie [Texts in the Ket Language. Siberian Lang. Minority Languages of Siberia: Our Cultural Heritage]. Available at: http://minlang.srcc.msu.ru/ru/textspage?field_word_lang_tid $\% 5 \mathrm{~B} \% 5 \mathrm{D}=44 \&$ field_text_type_ tid=All\&field_term_place_tid=All\&field_informant_nid $=\mathrm{Al}$ 
Vajda, E.A. (2009). Siberian Link with Na-Dene Languages, In Anthropological Papers of the University of Alaska, 6, 75-156.

Verner, G.K. (1996). Kety i ikh iazyk [The Kets and Their Language]. Krasnoyarsk, Krasnoyarsk Regional Institute of Teacher Training.

Verner, G.K. Pesn' o moem brate: na ketskom iazyke [The Song about my Brother: in the Ket language]. Available at: http://siberian-lang.srcc.msu.ru/ru/sintaksichyeskiy_proyekt_RFFI/ket

Volodin, A.P. (2005). Klass slov-opredelitelei v eniseiskikh iazykakh (sopostavitel'nyi analiz na material ketskogo, iugskogo i kottskogo iazykov) [The Class of Determinant Words in the Yenisei Languages (the Comparative Analysis Based on the Ket, Yug and Kott languages), In Tomsk State Pedagogical University Bulletin. Series: Humanities (Philology), 4 (55), 198-199. Available at: https://cyberleninka.ru/article/v/e-a-kryukova-klass-slov-opredeliteley-v-eniseyskih-yazykahsopostavitelnyy-analiz-na-materiale-ketskogo-yugskogo-i-kottskogo-yazykov-tomsk

\section{Кетский язык}

А.А. Ситникова

Сибирский федеральный университет Россия, 660041, Красноярск, пр. Свободный, 79

Настоящая статья носит характер прикладного исследования: выполнена в рамках культурологического проекта по сохранению культуры коренных малочисленных народов Красноярского края путем создания детской литературы на языках этих народов. В статье отражень ключевые характеристики кетского языка и культуры -места проживания кетов, проблема этногенеза, искусство кетов, шаманизм, тотемные верования и другие аспекты. В основной части статьи проанализированы имеющиеся лингвистические материаль о кетском языке и описан корпус текстов на кетском языке, существующих в данное время в открытом доступе. Особенный акцент ставится на цеенности оцифровки лингвистических данных о кетском языке в условиях виртуализации современной культуры и необходимости проведения междисииплинарных исследований кетского языка (лингвистика и культурология). Выдвигается гипотеза, что накопленные в течение XX-начала XXI в. лингвистические данные о кетском языке могут быть положены в основу дальнейших культурологических исследований ключевых концептов кетской культуры (например, «медведь»), которые позволят воссоздать картину мира в культуре коренных народностей сибирского Севера, а также сочиального проектирования методов эффективного сохранения и развития аутентичной культуры кетов путем издания детской литературы на кетском языке для обучения родному языку молодого поколения кетов с дошкольного возраста.

Ключевые слова: кетский язык, кетская культура, енисейские языки, культура коренных малочисленных народов Красноярского края, корпус текстов на кетском языке.

Исследование выполнено при поддержке Красноярского краевого фонда науки в рамках реализачии проекта: «Разработка научно-методического обеспечения сохранения уникального культурного наследия для кетской и энещкой этнокультурных групп коренных малочисленных народов Севера, Сибири и Дальнего Востока, проживающчих на территории Красноярского края.

Научная специальность: 24.00.00 - культурология. 